\title{
Classification of change detection algorithms for object-based applications
}

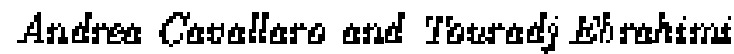

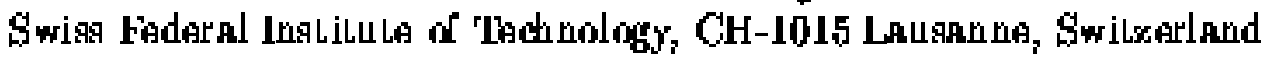 \\ rlal: +41 21 698 4725; lax: +41 21 693 7600; A-mail: ardroa. Lagallarosepfl. ch
}

\begin{abstract}
ABSTRLAT
Ohange detartinn le a temporal angmomtation tosl alm-

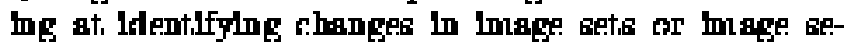

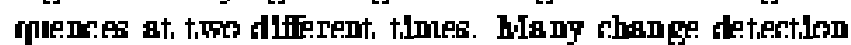

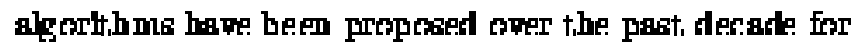
the gemeratlon of oldeo objects $\mathrm{m}$ a witle range of appllchtlone, moging from interartlon multumatla to remote Eirwelllance. hInet, of these algorlthme are tallored to the Exedife application at, hand. Therefore there le a next of a gen-ral moxtel for change detertion whlrh colld alp port. the cholse of the optlmal rhange detectlon Etrat

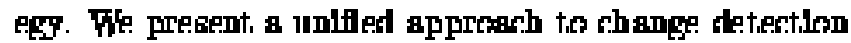
basod on a 1-zitep model phange detation algorlthme proposed in the llteratime are arralyosed in torme of the folr bidlding blorke of the proposed moxlal. Thls atilty

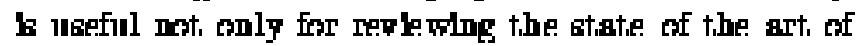

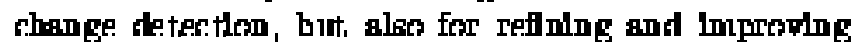

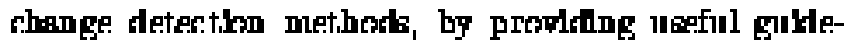
lines for the better' llag of the algorlthme.
\end{abstract}

\section{Introdnation}

Ohange detentun $\mathbf{k}$ an Important, tosl for mang mm-

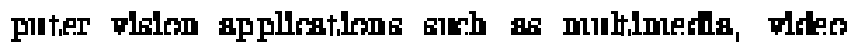

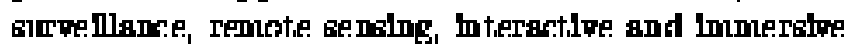

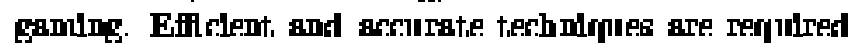
to detart, and label the changes In Imlage agte or Inlage

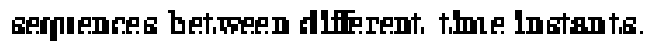

The gemeral rej|lrememte for change detertinn algo-

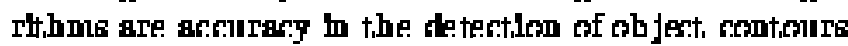

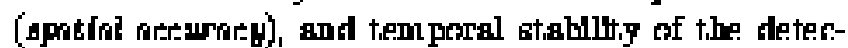

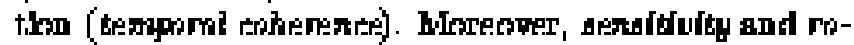

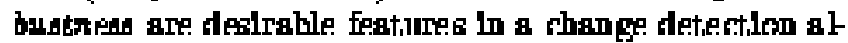

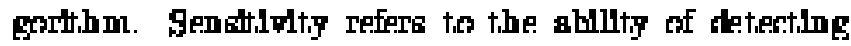
changes of emlall mapnltilde. Fobuletiness tan be vem

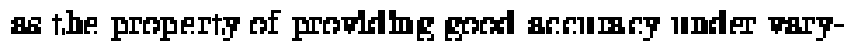
Ing crondtions, for example llumulnation changes. Othar

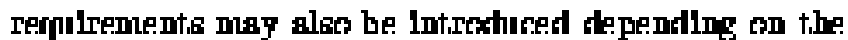

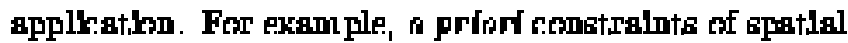

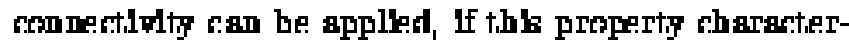
Ires the target, of the detextlon prosess.

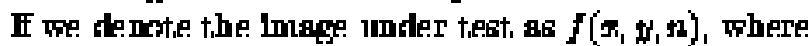

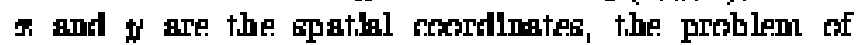

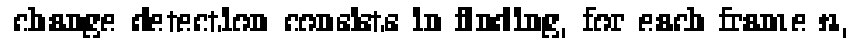

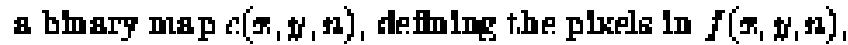
whleh hase changed with reapent, to the refereman lmage

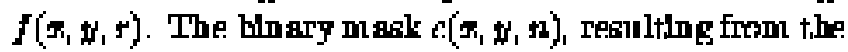
change detartion angly 허, le defined as

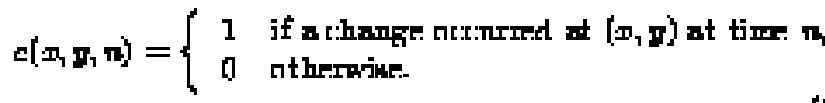

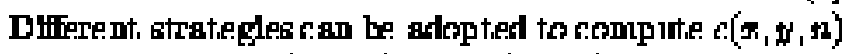

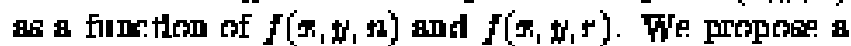
derrin frestlon of the chenge detation problem into folr

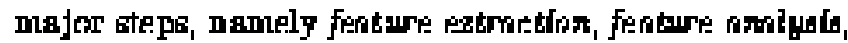

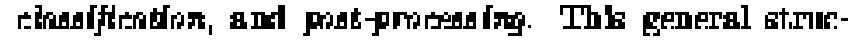

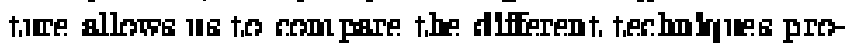
posed in the llteratilre. The black thagram of the proposed axhmue le ahom in Flgire 1.

The cholfes related to the change detertion algo-

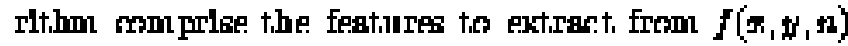

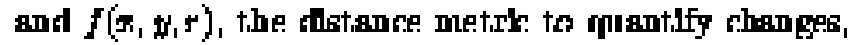

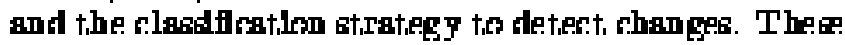

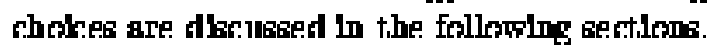

\section{A d-atep model tor thamge detestion}

\subsection{Feature extraction}

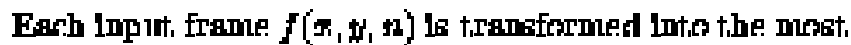

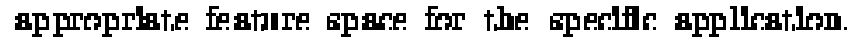

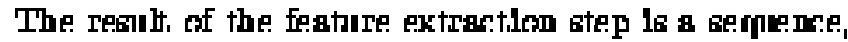

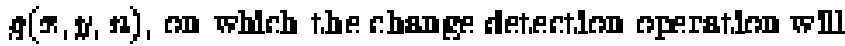

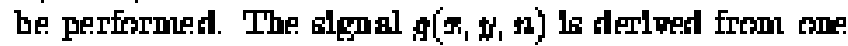
Imige only (1.e., 1t, does mot, contaln motion informatlonj. Th adriplly the notation in thle exetton, we will

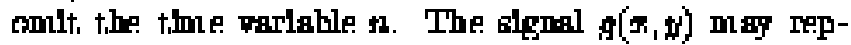

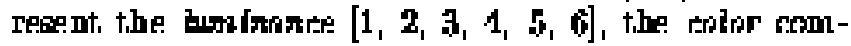
ponente [7, 9], or more crmples featurs. Hore crm-

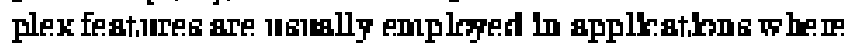

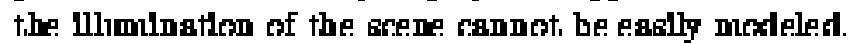
Lewel llnes [10], edge mape [11], wettor represomtaturn of Inlage reglons [12], and albeto Imagea [13] are examplas

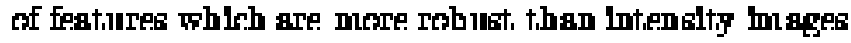
for change detatilon unter parging llbmination.

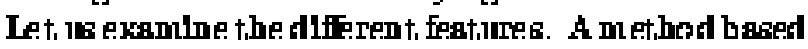

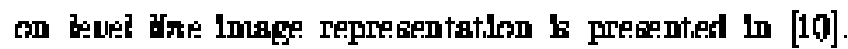




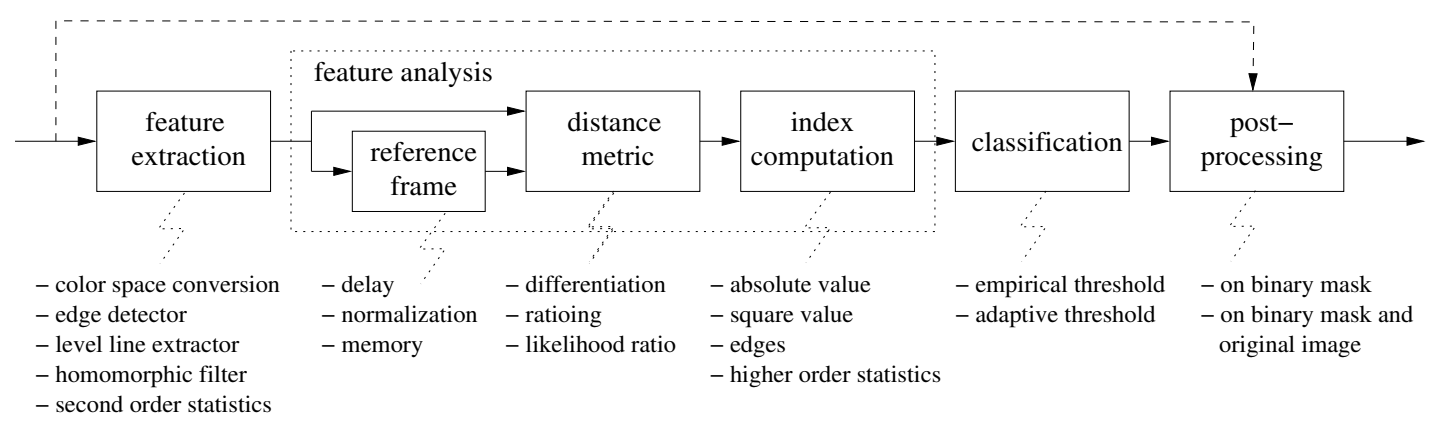

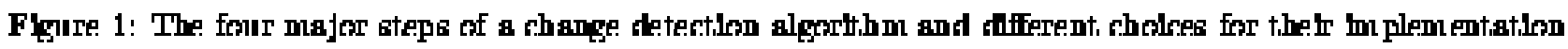

Thle apprearh explolte the fart, that, a glotal llliminatilon rarlation changes the mimber, but, not, the the ge-

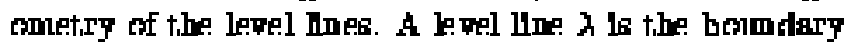

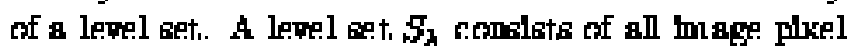

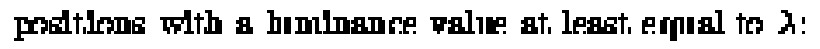

$$
S_{h}=\{(m, t): f(m, t) \geq \lambda\}
$$

The Image contalming the lewal llone can be exprasos,

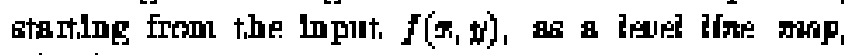

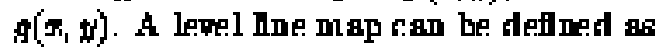

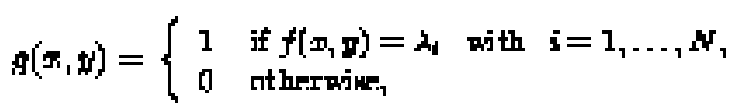

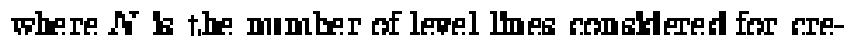
at血g the map.

Basat on the agme pindiple as lowal llnes, algorlthme

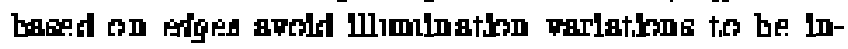
terpretat as atructiliral changes [11]. The llog of eftges

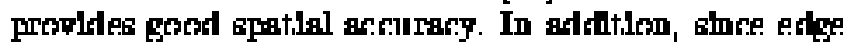
mape are bl-lewal lmages, they are crom omlent, from crmplitatlon and atorage wers polnte.

Another lllimination lowarlant, fegtilure for change de-

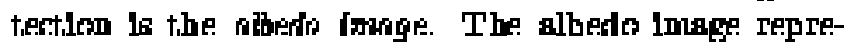
oonte the reflectance component, of an lmigge, whleh le

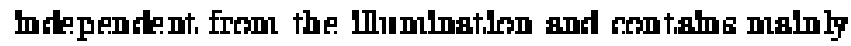

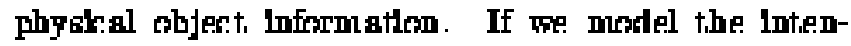

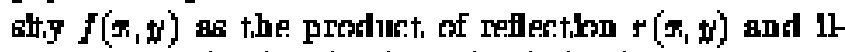

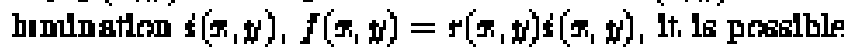
to extrant, the reflectance coniponent. (albeto) by apploing a homomorphle fllter [1:3] to the inpit. intemat-

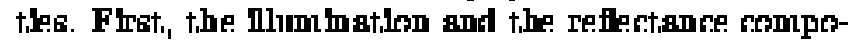
ment, are apparatat bg applying a log-flter, log $f(\mu, t)=$

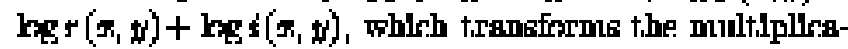

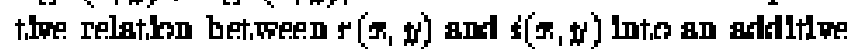

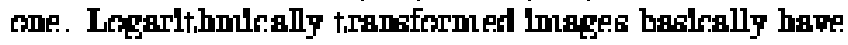

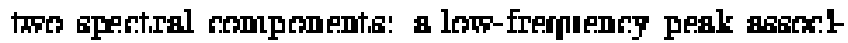
ated malmig whth lllominatlon, and a mid- and blgh-

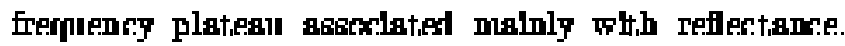

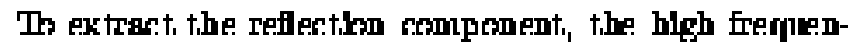

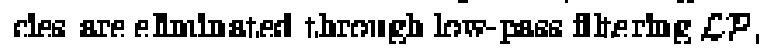

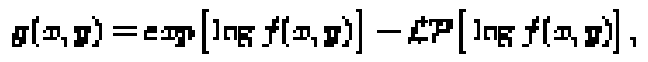

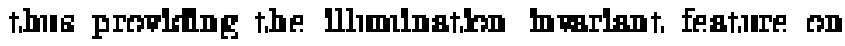
whleh the change tetectilon analgids can be appllet.

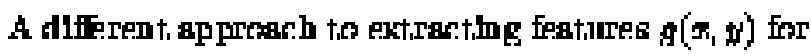
change detartlon inwolwe nuxtellng the intemedtg thetri-

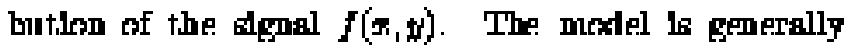

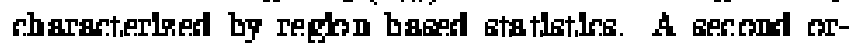
der moxtel le watly emploged to darthe the lox:al Intemedtig dlatrlbition in a reginn of an lmaga, for example the warlance and the mean of the repion [11], a rptedratle.

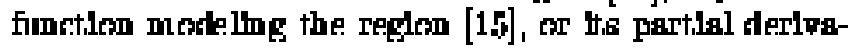

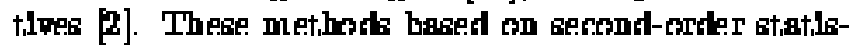
turs hage bexn emplopat in early rhange detectlon tech-

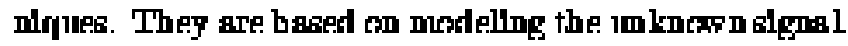
Theg are not. uast in modem chenge detertion and thep are reportat here only for aske of mmpletemess.

\subsection{Featore malyafa}

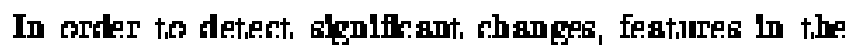

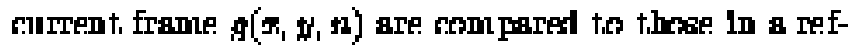

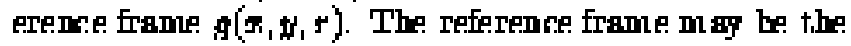

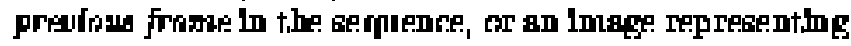

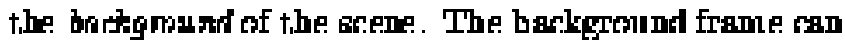
be flket, or lt, fan be uptated perixtirally. In the for-

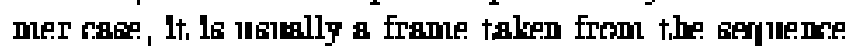
(e.g., the flrst, framue [5, 7]). In the lat,ter c:asa, temporal Intepratlon of the preplome frames [16] le luagt.

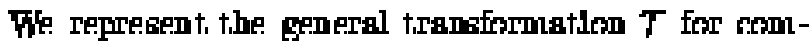

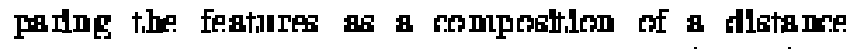

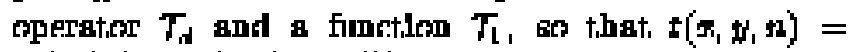

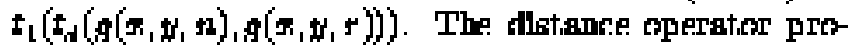

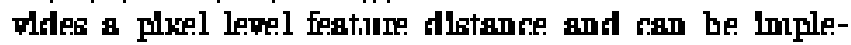

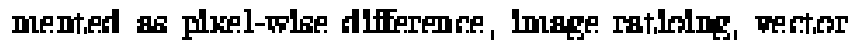

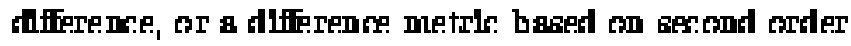

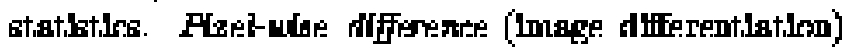

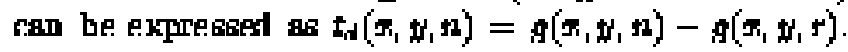

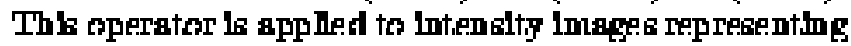
liminanee [16] or alor [T], and to bloary mape repre-

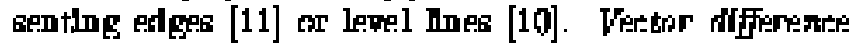

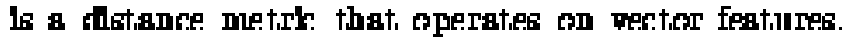

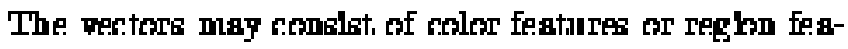
t.11res [12]. The [mogre motrin reprenente the ratils betwam

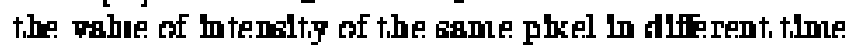


Inetanta:

$$
E_{i}\left[(\pi, g)=\frac{\theta[(\pi, \pi, \pi)}{\sigma(m, \pi, r)}\right.
$$

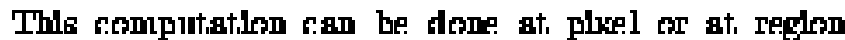
lewal and le robilet, to lllumlnation partatione. Diffor-

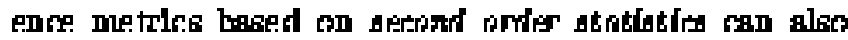

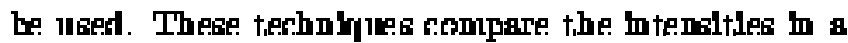

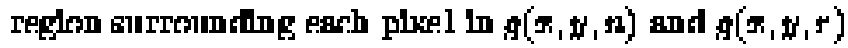

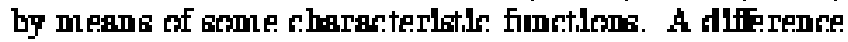

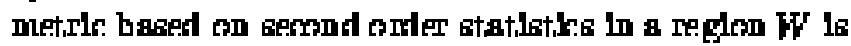

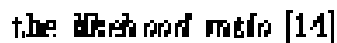

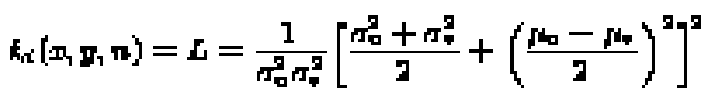

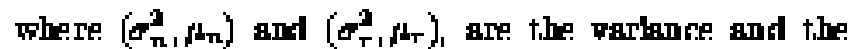

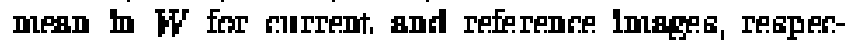
throly.

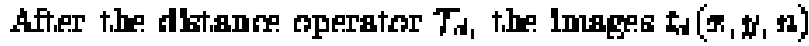

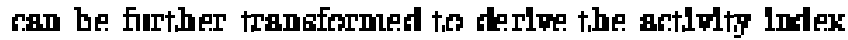

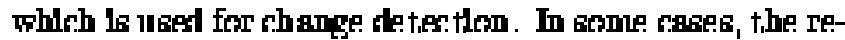

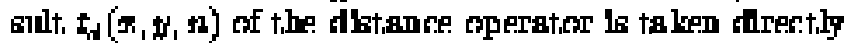

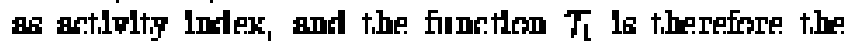

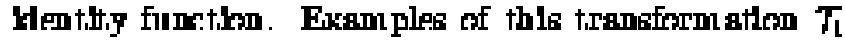

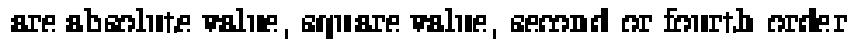
momente, and edges. Theg tam be applled to thforent.

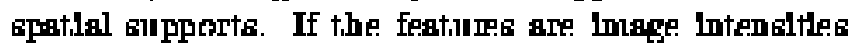

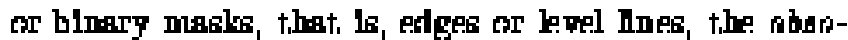

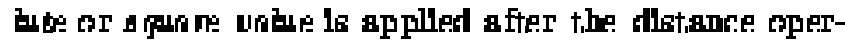

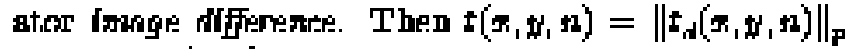

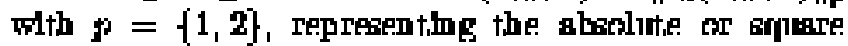

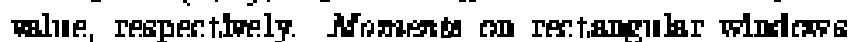

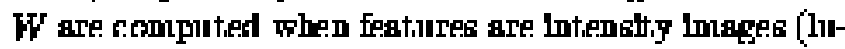

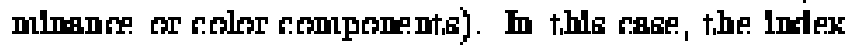
Barimue the frollow mg form

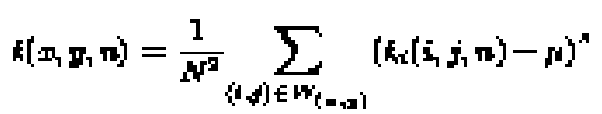

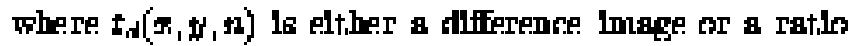
Image, a le the orter of the momemt, and th the mogem. Different, comblnation of $t,\left(m, t^{\prime}, t_{2}\right)$ and a hage bean

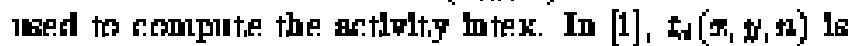

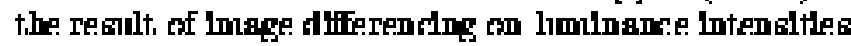
and $a=1$, that. Le $t(s, t, t 2)$ le a follth orter moment.

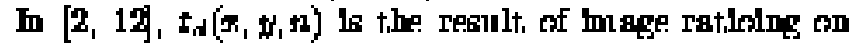

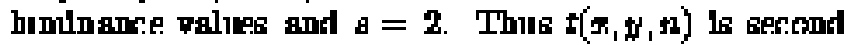
orter monumt. (eharting matel). Thle lodex of antloftg wan be attrlbited to the entlre raylon [2] [owerlappes

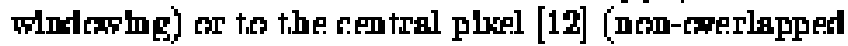

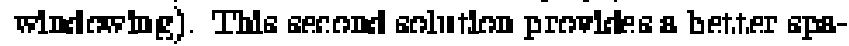
thial reasilition.

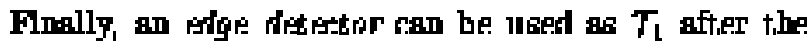

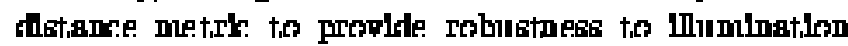
prarlatilone [T].

\subsection{Clamification}

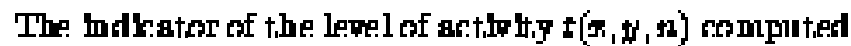

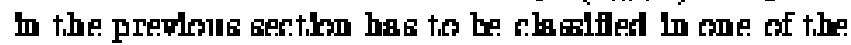

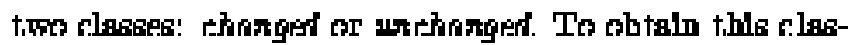

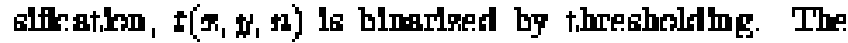

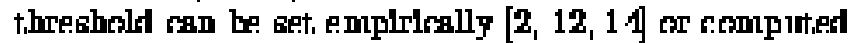

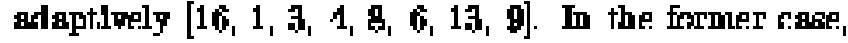
the thrahsit la flyed for all plkple in frame and all the

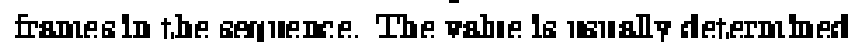
okperimumtally basat on a large database. In the latitar

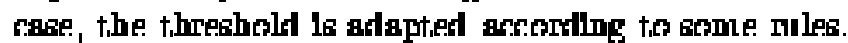

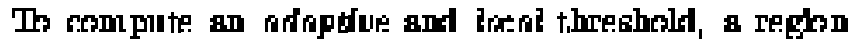

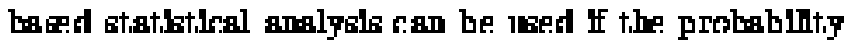

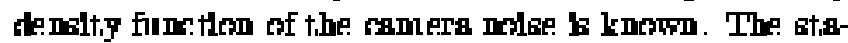

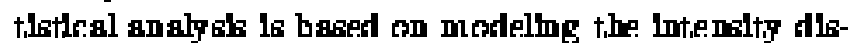

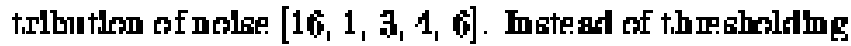

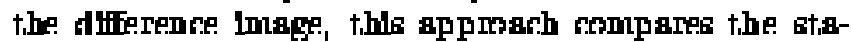

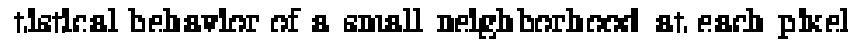

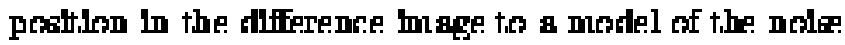

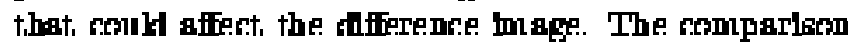

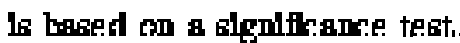

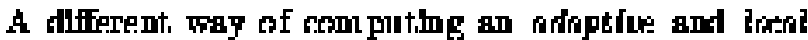
threahrid la presonted in [0], where the expotlal contextoral informution of earh plkel le takem into arcrilont. The threahrid for the tat, la adapted to the label monetella-

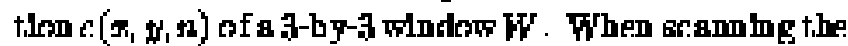
Imlage, only folr nelghboring labels in the calkal part, of the ndehborhose Wr are apallable. For thle reason, the Talue of the other folr le apprrkimates whth the labele

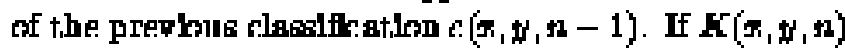
denstes the n1mber of plkels deterted as changed in the

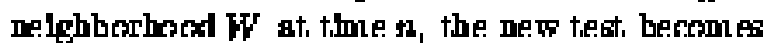

$$
E[(\pi, \pi, \pi)>r+H[A-K(\pi, \pi, \pi)]
$$

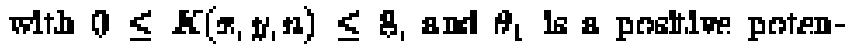

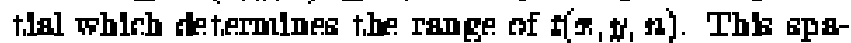
thally adaptlog thrahold allorse the creation of compant. and amusthly ahaped regione of change, and ratures

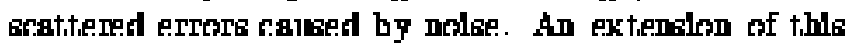

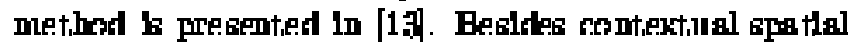
informatlon, temporal infrrmition is integrated in the

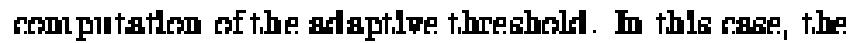
label $c(m, t,+1-1)$ of plkel $(\omega, t)$ in the pretione frame le alos constdered. The watio-temporally adaptlon threahold le glman by

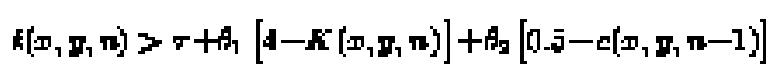

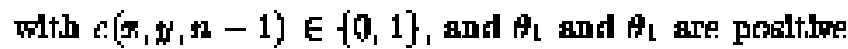
potemtilale.

\subsection{Pot-proseaging}

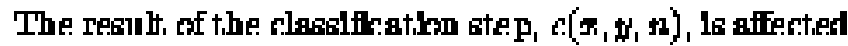

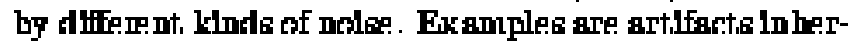

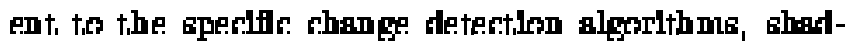

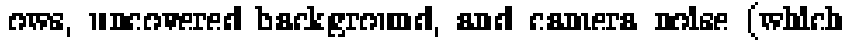
mag be not completely elloling ted by the detaxtion al-

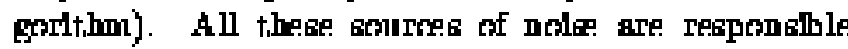

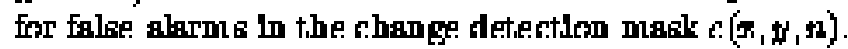


Th rethre the probablllty of false alarme, parthe prot-

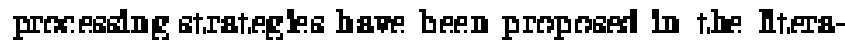

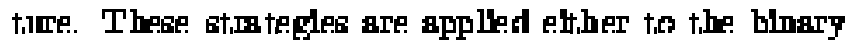
Image realt, of the rlasidf ration only, or to both the blnary lmages and the oridginal frame. In the frmer chase,

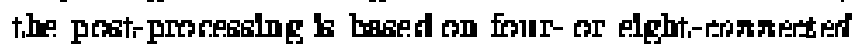

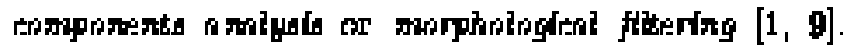

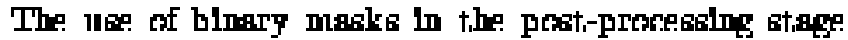
has the atrantage of rechidng the false alsm probs-

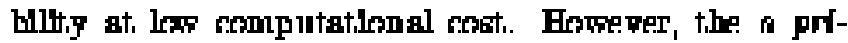

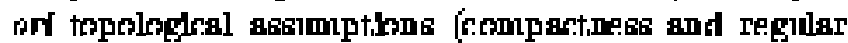
motoirs' on whlch ther are based mag not, alwage be

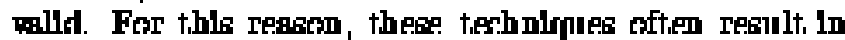

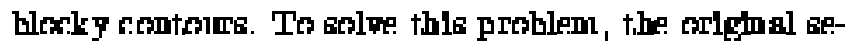

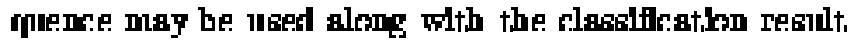
In the prot-processing. Minting, color and edge informustiron are topiral okamples of for tores that, are analpost to mprowe the epatlal arrolrary of the change detextlon ratilt. [19].

\section{Convation}

In the framework of emuntile vites object, extractlon based on motism, a unlfled approsich to chenge deterthon has besm proposed. Thle approanth le based on a demompotition of the problem into four major ateps:

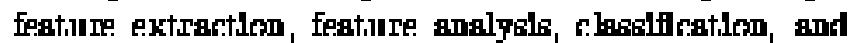

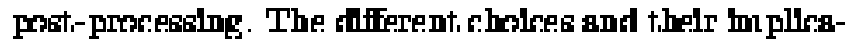
thone in the destgn of rhange detertion algorlthme hape

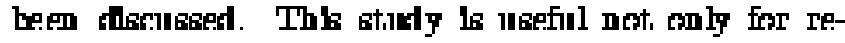
wlewing the atste of the art of change deterttron, but. als for reflulng and lmprowing chenge detextlon meth-

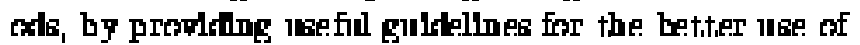
the algorithme. O1r elrTent, wrork is the Integration of

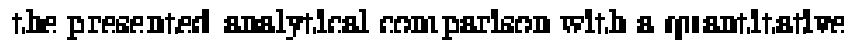

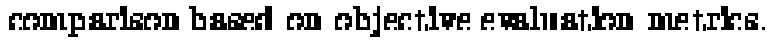

\section{Heterence}

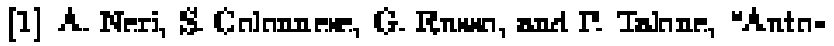

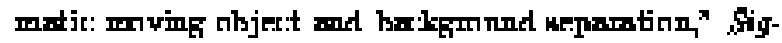

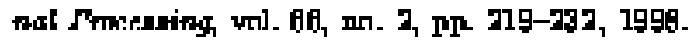

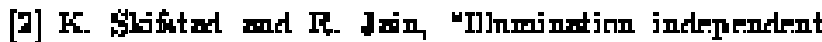

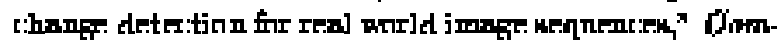

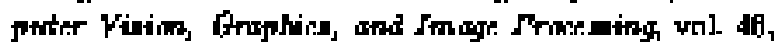

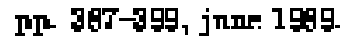

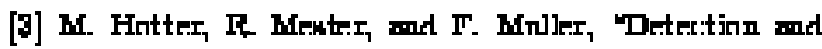

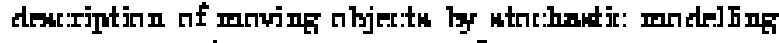

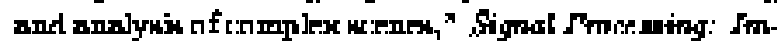

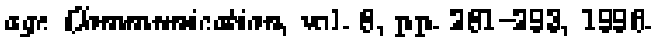

[d] T. Aarh, AL Kanp, and If Mroter, statikind madr]-

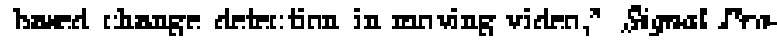

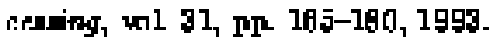

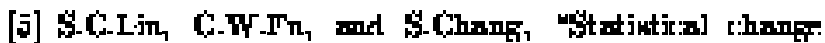

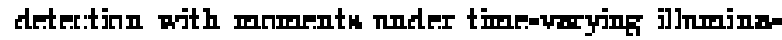

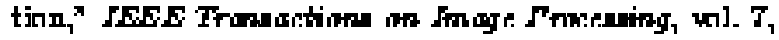
กา. 9, II- 175

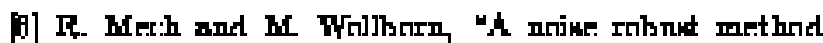

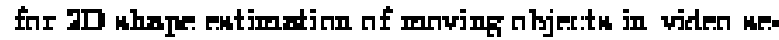

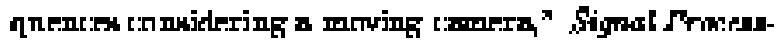

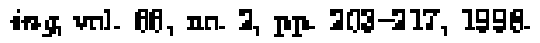

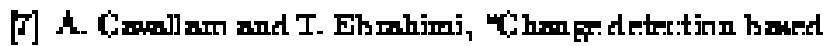

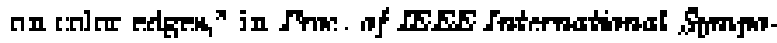

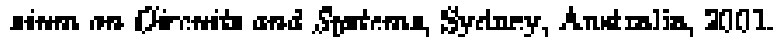

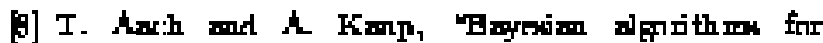

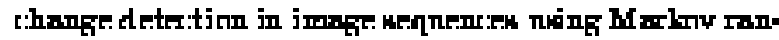

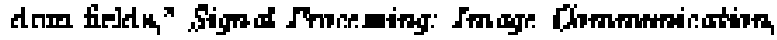

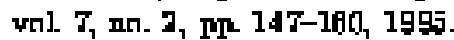

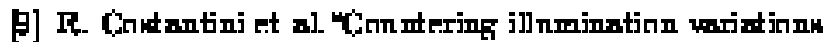

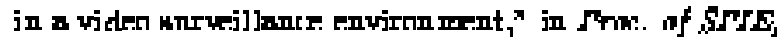

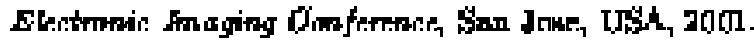

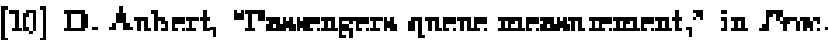

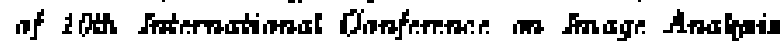

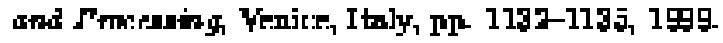

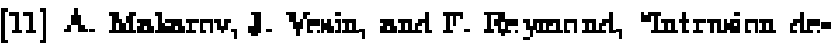

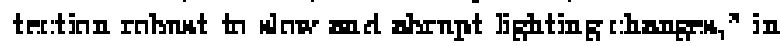

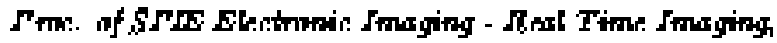

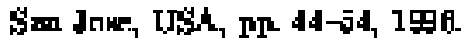

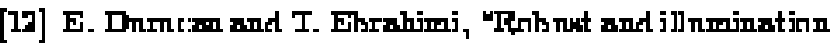

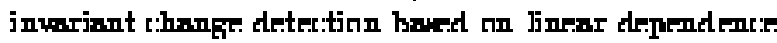
firr

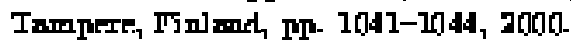

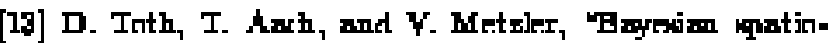

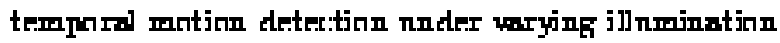

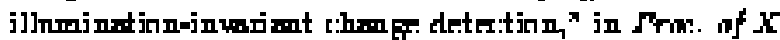

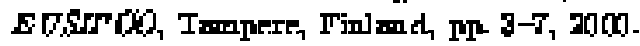

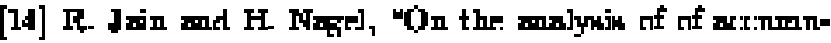

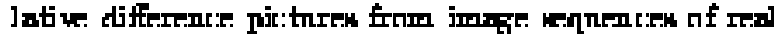

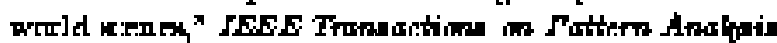

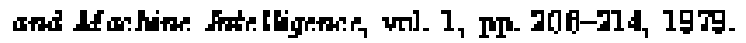

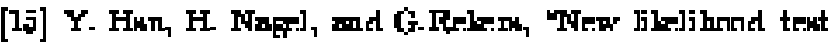

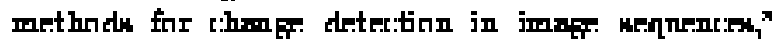

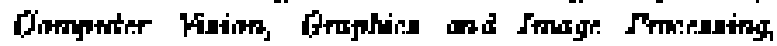

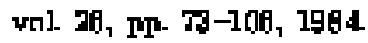

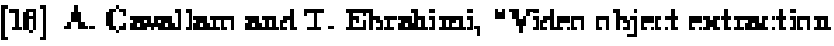

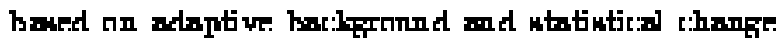

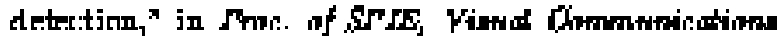

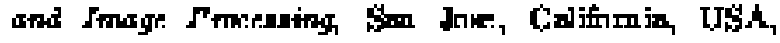
Ir. 4fis-4T3, 20011

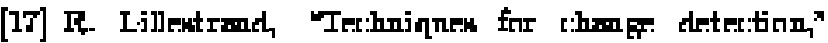

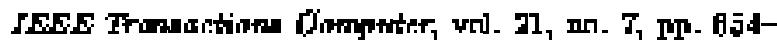

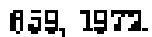

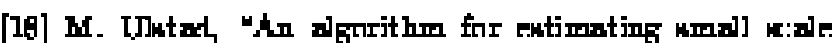

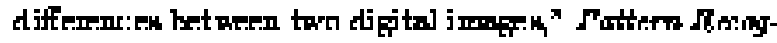

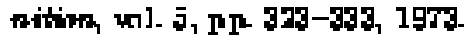

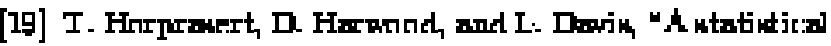

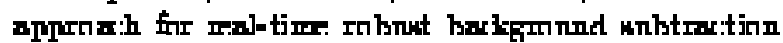

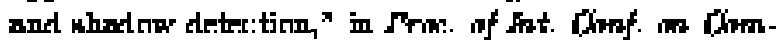

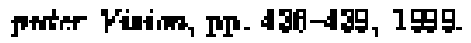

